\title{
Natural and economic effects of renewable energy sources in the developing countries: a case of Azerbaijan
}

\author{
Zhala Rzayeva ${ }^{1}$ Aysel Guliyeva ${ }^{2 *}$, and Arzu Miriyeva ${ }^{1}$ \\ ${ }^{1}$ SABAH CENTER, Azerbaijan State University of Economics (UNEC), 6, Istiglaliyyat str., AZ1001, \\ Baku, Azerbaijan \\ ${ }^{2}$ International Economy department, Azerbaijan State University of Economics (UNEC), 6, \\ Istiglaliyyat str., AZ1001, Baku, Azerbaijan
}

\begin{abstract}
This paper focuses in the natural and economic effects of renewable energy sources in the developing countries using a case of Azerbaijan. Traditional fuel supplies dependent on gas, oil, and coal are highly useful for the development of a country's economy. However, certain detrimental effects of these commodities on the environment have limited us to use these resources under clear cut-off points. As a result, we were able to turn our intuition into renewable energy sources. By using renewable energy sources, social, natural, and financial challenges can be ignored because these sources are considered harmless to the atmosphere, as there are little or virtually no fumes discharged, and toxic gases such as carbon dioxide, carbon monoxide, and sulfur dioxide. Renewable electricity would be a major advantage for power generation in the near future so we will reuse these assets to generate useful electricity. The paper discusses these and other issues with the implementation of renewable energy and assess the potentials of Azerbaijan in adapting this type of energy in the future.
\end{abstract}

\section{Introduction}

Alternative (renewable) energy will quickly become a significant contributor to climate change and these resources will be reused and produced usable energy repeatedly [1]. The three types of energy supplies that are commonly used are fossil, renewable, and nuclear [2]. Hydroelectric power, solar energy, wind energy, biomass, ocean oil, biofuel, geothermal fuels, and other green energy sources account for approximately 20 percent of overall global energy output.

On account of the expanded interest for energy because of the world's quickly developing populace, petroleum derivatives like coal, gas, and oil will be utilized to fulfill the need, bringing about impractical circumstances and various issues like petroleum product consumption, ecological and geological clashes, nursery impact, a dangerous atmospheric deviation, and change in the renewable energy is called clean energy since it is harmless to the ecosystem and discharges fewer gases; it is likewise advantageous to society across all

\footnotetext{
* Corresponding author: aysel.guliyeva10@gmail.com
} 
angles, including monetary, social, and natural [3]. Today, around 1.6 billion individuals do not have the access to electric power, and about 1.1 billion do not have access to drinking water [4]. Environmentally friendly power supplies can meet the entirety of the world's energy needs while likewise securing the climate and guaranteeing energy proficiency. Alongside the various advantages of these devices, a few disadvantages exist, for example, creation difference because of occasional changes, which is an ordinary event for wind and hydroelectric force plants; thus, exceptional plan and care are required, which are met by equipment and programming on account of advances in PC innovation. Table 1 groups the major environmentally friendly power sources and their different applications; it is anticipated that sustainable power will be perhaps the most basic sources later on; Table 2 gauges the world's sustainable power sources situation by 2040 .

Table 1. The most popular renewable energy sources and their usage

\begin{tabular}{|l|l|}
\hline Energy resources & The choice for energy transfer and consumption \\
\hline Hydropower & production of electricity \\
\hline Biomass & $\begin{array}{l}\text { Production of heat and fuel, pyrolysis, gasification, and } \\
\text { digestion }\end{array}$ \\
\hline Geothermal & Hydrothermal, hot rock, and urban heating \\
\hline Solar & Solar lighting systems, solar dryers, and solar ovens \\
\hline Direct solar & $\begin{array}{l}\text { Photovoltaics, solar power generation, and heating } \\
\text { systems }\end{array}$ \\
\hline Wind & Wind turbines, wind generators, and windmills \\
\hline Wave & a variety of styles \\
\hline Tidal & Tidal drain, barrage \\
\hline
\end{tabular}

There are several challenges in the twenty-first century, particularly in developing countries, such as meeting the demands of thousands of humans who still lack access to easy, sustainable energy supplies and engaging in the international context of sustainable, reduced energy generation.

Fortunately, the aim of lowering greenhouse gas emissions may be compatible with other energy-related priorities, such as the production of sustainable indigenous resources and the elimination of local forms of pollution. If they also lead to other social and economic growth goals, renewable energy strategies are more likely to be successful. To optimize positive synergies where they occur, policymakers should evaluate strategies to get the most optimal solutions [5].

Since it is relatively sunny and windy, as well as a large hydro, biomass, and geothermal deposits, Azerbaijan has a huge untapped renewable energy capacity. The government is working on legislation to encourage the use of clean energy sources [6]. Auctions and tenders are proposed as funding structures in the draft clean energy legislation. It also includes the development of other legal papers, such as a PPA draft and a connection agreement. Also, guidelines for auctions and rules for the implementation of net-metering/net-billing systems are being drafted.

Table 2. A global renewable energy scenario in place by 2040

\begin{tabular}{|l|l|l|l|l|l|}
\hline $\mathbf{2 0 0 1}$ & $\mathbf{2 0 1 0}$ & $\mathbf{2 0 2 0}$ & $\mathbf{2 0 3 0}$ & $\mathbf{2 0 4 0}$ & $\mathbf{2 0 5 0}$ \\
\hline $\begin{array}{l}\text { Total consumption (million } \\
\text { tons equivalent) }\end{array}$ & 10,038 & 10,549 & 11,425 & 12,352 & 13,310 \\
\hline Biomass & 1080 & 1313 & 1791 & 2483 & 3271 \\
\hline Large hydro & 22.7 & 266 & 309 & 341 & 358 \\
\hline Geothermal & 43.7 & 86 & 186 & 333 & 493 \\
\hline Small hydro & 9.5 & 19 & 49 & 106 & 189 \\
\hline
\end{tabular}




\begin{tabular}{|l|l|l|l|l|l|} 
Wind & 4.7 & 44 & 266 & 542 & 688 \\
\hline Solar thermal & 4.1 & 15 & 66 & 244 & 480 \\
\hline Photovoltaic & 0.1 & 2 & 24 & 221 & 784 \\
\hline Solar thermal electricity & 0.1 & 0.4 & 3 & 16 & 68 \\
\hline Marine (tidal/wave/ocean) & 0.05 & 0.1 & 0.4 & 3 & 20 \\
\hline Total RES & 1365,5 & 1745,5 & 2964,4 & 4289 & 6351 \\
\hline $\begin{array}{l}\text { Renewable energy } \\
\text { contribution source (\%) }\end{array}$ & 13.6 & 16.6 & 23.6 & 34.7 & 47.7 \\
\hline
\end{tabular}

As a result, the ongoing discussion on energy security must be expanded to include the potentially disastrous effects of high energy prices in a hydrocarbon-based global energy system, as well as climate change. Extreme weather conditions will restrict access to energy supplies, and climate rises will rapidly alter the pattern of global energy markets, resulting in new and often negative interdependence relationships. Developing countries need more reliable and sustainable energy supplies, as well as new technical solutions that allow for more efficient use of conventional and renewable energy sources. In the nations of the South, more predictable help for environmentally agreeable advancement dependent on renewables is required. The equivalent can be said for worldwide advancement help bundles that incorporate innovation sharing and environmentally friendly power.

We all should save electricity, increase energy conservation, and prioritize renewable energy sources. On a global scale, we should encourage renewable energies, as well as energy conservation and efficiency technologies. Meeting these problems is in both developing and developed countries' best interests. Renewable energy must be promoted by the European Union and its member countries. They have the political, analytical, and technical skills, as well as the financial capital, to not only direct the global discussion on renewable energy but also to push global action. Renewable energy is the best solution to energy poverty because it reduces $\mathrm{CO}_{2}$ emissions, slows the global warming trend, and provides a viable model for long-term energy strategies [7]. It is also a business opportunity, not only a requirement.

\section{Policies on renewable energy in developing countries}

The main impediments to renewable energy adoption in developed countries derive from a lack of technical know-how to build appropriate power systems. The main concern for adopting technology in developed countries is their feasibility and appropriateness, as well as their ease of use. The second is an educated and convinced public to use this energy, and the third is a barrier that removes effort in political and large economic concerns to the strong promotion of the above implementations so that policymakers can carry out this agenda. Apart from the above factors, societal changes in behavior are a major influence on society's ability to respond to these developments, and these will be more difficult to solve if these problems are ignored. Despite some issues, renewable energy in developed countries, especially in Asia, has shown how to inspire efficient renewable energy installation to meet their rising energy needs. These commitments are centered around limited scope environmentally friendly power sources including little hydro, biomass, and geothermal energy.

Table 2 shows the general yield of sustainable power for power generators, just as the portion of limit conveyed in created nations. As per this table, the net inexhaustible force limit in created nations rose by 88.5 percent somewhere in the range of 2003 and 2009, expanding from $58.1 \mathrm{GW}$ in 2003 to $109.5 \mathrm{GW}$ in 2009 . Wind, sunlight based photovoltaic, and biomass power are the three principal supporters of sustainable power item advancement from 2003 to 2009, with wind power representing 1,333.0 percent (from $3 \mathrm{GW}$ in 2003 to 40 
GW in 2009), sun based photovoltaic representing 25.0 percent, and biomass power representing 33.3 percent. Sustainable electric energy projects were the harbingers of generously expanding clean energy creation volumes to kill ozone-depleting substance emanations from 1993 to 2007.

Table 3. RES by type (2003 and 2009)

\begin{tabular}{|l|l|l|l|l|}
\hline \multicolumn{1}{|c|}{ RES energy by type } & \multicolumn{2}{|c|}{$\mathbf{2 0 0 3}$ in GW } & \multicolumn{2}{c|}{ 2009 in GW } \\
\hline All countries & $\begin{array}{c}\text { Developing } \\
\text { countries }\end{array}$ & All countries & $\begin{array}{c}\text { Developing } \\
\text { countries }\end{array}$ \\
\hline Small hydropower & 56 & 33 & 60 & 40 \\
\hline Wind power & 40 & 3 & 159 & 40 \\
\hline Biomass power & 35 & 18 & 54 & 24 \\
\hline Geothermal power & 9 & 4 & 11 & 5 \\
\hline Solar photovoltaic power & 1.1 & 0 & 0.7 & 0 \\
\hline Solar thermal power & 0.4 & 0 & 21 & 0 \\
\hline Ocean power & n.a & m.a & 0.3 & 0 \\
\hline $\begin{array}{l}\text { Total renewable power } \\
\text { capacity }\end{array}$ & 141.5 & 58.1 & 306 & 109.5 \\
\hline $\begin{array}{l}\text { Total hydropower } \\
\text { (including the Large } \\
\text { Hydro Power) }\end{array}$ & 872 & & & \\
\hline
\end{tabular}

Source: REN 21 [8]

Developing countries have established small power producers (SPP) systems to support renewable energy production during those years. They began with the addition of new solar small power projects (SPP) to the nation's energy source, which was funded by private power projects and shared risk with the government. Ferrey [9] conducted an analysis to test the small power supply program (SPP) in five Asian countries with advanced systems (e.g. Thailand, Indonesia, India, Sri Lanka, and Vietnam). He discovered that by an open mechanism involving consumer, producer, and lender trust, additional incentives representing the fuel variety and environmental benefits are used to assist higher-cost renewable energy and smaller SPP.

\section{Renewable energy resources in the Republic of Azerbaijan}

Azerbaijan is a country with huge sustainable power creation potential. The nation has a plentiful breeze and sunlight-based assets, just as promising biomass, geothermal, and hydropower potential. The public authority has effectively defined an objective of adding $420 \mathrm{MW}$ of environmentally friendly power limit by 2020 to understand this chance. The nation has continued to send projects utilizing designing, acquisition, and development (EPC) contracts, guided by this objective. Notwithstanding, in contrast with the size of the country's accessible assets and long-haul objectives, the commonsense arrangement has been negligible $[10,11]$.

Past monetary broadening, a higher portion of an environmentally friendly power in the energy blend will have a few benefits. Sustainable power can make new openings in a world that have generally been overwhelmed by oil and gas, by taking into consideration mechanical advancement and opening up new business sectors for the monetary worth turn of events and GDP development. Besides, expanded environmentally friendly power arrangement, joined with proceeded with enhancements in energy proficiency, could lessen 
homegrown oil and gas utilization, opening up freedoms to create extra income through sends out and decrease homegrown sponsorships.

Currently, Azerbaijan is a net exporter of energy. Oil, gaseous petrol, and power are traded from the area. Azerbaijan's energy needs are met principally through homegrown creation, which is right now reliant on the extraction of the country's hydrocarbon saves, specifically oil and petroleum gas. The Caspian Basin has massive oil holds, which Azerbaijan imports to Russia, Kazakhstan, Turkmenistan, and Iran are which are assessed to be seven billion barrels in 2018 [12], which is similar to the North Sea saves from many years prior. Azerbaijan trades multiple times its all-out conclusive energy utilization, as demonstrated in Table 4. The decrease in essential sustainability and waste creation is because of fluctuating hydropower age and diminished utilization of wood as a feedstock for energy creation. Upgrades in region warming and the development of gas-terminated water radiators likewise decreased the utilization of wood.

Table 4. Energy balance of Azerbaijan in 2010-2017 (ktoe)

\begin{tabular}{|c|c|c|c|c|c|}
\hline & 2010 & 2014 & 2015 & 2016 & 2017 \\
\hline $\begin{array}{l}\text { Primary production, } \\
\text { including: }\end{array}$ & 68254.6 & 61132.0 & 61084.2 & 59977.6 & 57036.0 \\
\hline Crude oil (with NGL) & 52312.5 & 43295.9 & 42835.5 & 42240.9 & 39810.4 \\
\hline Natural gas & 15555.6 & 17565.1 & 17947.3 & 17463.5 & 16967.6 \\
\hline Renewables and waste & 386.5 & 271 & 301.4 & 273.5 & 258 \\
\hline $\begin{array}{l}\text { Net imports of all } \\
\text { energy products }\end{array}$ & -54300.2 & -45869.5 & - 45747.4 & -44693.0 & - 40789.6 \\
\hline Total energy supply & 12566.5 & 15085.5 & 15569.4 & 15393.5 & 15471.9 \\
\hline $\begin{array}{l}\text { Transformation } \\
\text { processes }\end{array}$ & -2692.7 & -3491.3 & -3819.7 & -3731.0 & -4020.6 \\
\hline $\begin{array}{l}\text { Energy industry own- } \\
\text { use }\end{array}$ & 931.1 & 1188.2 & 1167.0 & 1133.0 & 1147.7 \\
\hline $\begin{array}{l}\text { Total final energy } \\
\text { consumption }\end{array}$ & 6710.6 & 8241.7 & 8304.3 & 8644.9 & 8210.0 \\
\hline
\end{tabular}

Source: State Statistical Committee of Azerbaijan [13]

In its Strategic Road Map on National Economic Perspectives of Azerbaijan, the country's administration underlines the significance of differentiating the economy and decreasing dependence on the oil and gas areas. In this specific circumstance, expanding the portion of sustainable power in the energy blend can give a few benefits, including expanded government assistance and occupation creation, energy solidness, financial enhancement, and GDP development $[14,15]$.

Sustainable power, by offering new roads for specialized advancement and new businesses for monetary worth improvement in a world customarily overwhelmed by oil and gas, will catalyze new position open doors in a nation generally overwhelmed by oil and gas. The country's broad involvement with the oil and gas area gives a strong establishment to the appropriation of environmentally friendly power advances. For instance, aptitude acquired from the seaward oil and gas framework has been utilized to build up the seaward wind industry in Norway, while mastery acquired from seaward oil and gas foundation has been utilized to build up the seaward wind industry in Canada.

The State Oil Company of Azerbaijan Republic (SOCAR) - the nation's entirely statepossessed public oil and gas organization - is a central participant in the country's energy area. SOCAR has effectively introduced wind and sun-based PV in the Tagiyev oil and gas 
area and is investigating sustainable power alternatives for providing the ability to seaward offices while keeping up its dependence on conventional fuel sources.

In addition, expanded sustainable power organization, joined with proceeded with upgrades in energy effectiveness, could lessen homegrown oil and gas utilization, giving a chance to produce extra income through sends out and decrease homegrown sponsorships. Sustainable power is additionally the most mainstream low-carbon elective for Azerbaijan's environmental objectives. In its Nationally Determined Contribution (NDC) under the Paris Agreement, the nation swore to diminish GHG emanations by $35 \%$ by 2030 contrasted with the 1990 base year. To meet this objective, the NDC as of now accentuates the utilization of option and sustainable power sources.

The advancement of environmentally friendly power could likewise add to energy framework flexibility in Azerbaijan. For instance, appropriated sustainable power frameworks, joined with expanded utilization of battery stockpiling, can improve the security of supply. Given the extended expansion in public energy interest, sustainable power likewise gives a specialized answer for the requirement for quick force age limit organization, attributable to generally more limited lead times for project development when contrasted with traditional sources. The public authority ought to figure a drawn-out technique to raise public mindfulness and limit concerning sustainable power, focusing on state organizations, neighborhood organizations, and inhabitants. Accreditations might be fused into preparing educational programs, with an accentuation on improving neighborhood administration and support abilities to improve open positions. Specific limit working in sustainable power strategy and guideline, just as sustainable power project evaluation strategies, may uphold government offices. Courses laying out the possibilities for setting up sustainable power organizations, just as subtleties on accessible government subsidizing plans and accomplices, could be given to the private area. Affirmation and preparing in an assortment of sustainable power applications and related advancements for both force and non-power applications can likewise be valuable.

A greater public understanding of the effects of green energy and how they relate to Azerbaijan's overall economic condition may be beneficial. A series of information events could be used to organize public awareness, especially in areas with a high potential for renewable energy growth. Also, various other formats, such as social media promotions, contests, and challenges for students in schools, higher education institutions, and colleges, as well as municipal activities in specific towns and cities, may be designed to increase awareness.

\section{Conclusions}

Overall, the customary characteristic assets like oil, gas, and coal are extremely fundamental for the improvement in economies of a world. A country like Azerbaijan is for the most part dependent on conventional fuel sources, notwithstanding perceiving the negative effects on wellbeing and the environment, like the nursery impact, worldwide environmental change impact, etc. Azerbaijan is blessed with both environmentally friendly power sources, for example, the hydro, wind, and geothermal, and it is additionally an ideal area for the sun-based force age. Nonetheless, the greatest difficulties in producing power from clean energy assets are subsidizing and governmental issues. For the gathering of elective fuel sources, all contemplations like ozone harming substance outflows, asset supply, land prerequisites, water use, financial impacts, and force age cost are thought of. Wind power age is thought to have minimal measure of water use, a minimal measure of relative ozone harming substance outflows, and the best friendly impacts. It is perceived as quite possibly the most feasible environmentally friendly power fuel source, behind just hydropower, sunlight-based force energy, and geothermal energy. Biomass is believed to be 
ideal for limited scope production in light of the fact that it saves a lot of carbon. The appropriate utilization of environmentally friendly power energy frameworks will bring about neighborhood occupations, improved wellbeing, work openings, work development, client inclination, expectation for everyday comforts change, social control creation, pay creation, segment changes, social security creation, and local area advancement. Alongside the upsides of efficient power energy assets, they are hard to fabricate and are helpless against nearby ecological and climate conditions. In contrast with different projects, their determining, execution, and arrangement require additionally thought and experience.

\section{References}

1. R. Bora, R. Wang, F. You, ACS Sustainable Chemistry \& Engineering, 8(43), 1635016363 (2020)

2. I. Č́ábelková, W. Strielkowski, D. Streimikiene, F. Cavallaro, J. Streimikis, Technological Forecasting and Social Change, 163, 120477 (2021)

3. S. Kolosok, T. Pimonenko, A. Yevdokymova, N. Hajiyev, M. Palienko, L. Prasol, Marketing and Management of Innovations, 4, 50-60 (2020)

4. O. Durodola, V. Nabunya, M. Kironde, C. Nevo, J. Bwambale, World Water Policy, 6(2), 176-201 (2020)

5. S. Kalyugina, W. Strielkowski, L. Ushvitsky, E. Astachova, Journal of Security \& Sustainability Issues, 5(2), 297-304 (2015)

6. N. Vidadili, E. Suleymanov, C. Bulut, C. Mahmudlu, Renewable and Sustainable Energy Reviews, 80, 1153-1161 (2017)

7. E. Lisin, D. Shuvalova, I. Volkova, W. Strielkowski, Sustainability, 10(4), 1111 (2018)

8. REN21, https://www.ren21.net/reports/global-status-report (2020)

9. S. Ferrey, http://regulationbodyofknowledge.org (2004)

10. A. Ciarreta, E. Ahmadov, Economics, 6(2), 75-95 (2019)

11. U. Aydine, https://www.econstor.eu/handle/10419/222759 (2019)

12. A. Ibrayeva, http://www.zbw.eu/econis-archiv/bitstream/11159/2112/1/1028133111.pdf (2018)

13. State Statistical of Azerbaijan, https://www.stat.gov.az/source/balance fuel/?lang=en (2020)

14. R. Pomfret, The Central Asian economies in the twenty-first century: Paving a New Silk Road (2019)

15. S. Humbatova, N. Hajiyev, International Journal of Energy Economics and Policy, 11(1), 341 (2021) 